\title{
4 種膜型人工肺における臨床的性能評価
}

二重 実 吉田秀人 小林靖雄 橋本武昌 田崎昭夫 杉田隆彰1) 松山克彦1) 西澤純一郎 ${ }^{1)}$ ：吉田和則 ${ }^{1)}$ 松尾武彦 ${ }^{1)}$ 徳田順之 ${ }^{11} \quad$ 松本雅彦 ${ }^{11}$

【要旨】 MENOX AL-6000 $\alpha$, Capiox RX 25R, QUANTUM HF-6700, QUADROX の 4 種類 の膜型人工肺のガス交換能を比較した。なお，血液ガス分析は成人開心術症例において完全体外循 環中の人工肺入口と人工肺出口から採血し行った。酸素加能については, 酸素添加量はQUANTUM HF-6700 と MENOX AL-6000 $\alpha$ が高值となったが, 有効肺血流量率 (Qp/Qt) では 4 種類の 人工肺に差はなかった。炭酸ガス排出能については, Capiox RX25R が炭酸ガス排出量および炭酸 ガス較差分圧比 $\left(\Delta \mathrm{CO}_{2} / \mathrm{PaCO}_{2}\right)$ が高值となった。しかしながら, $\mathrm{PaO}_{2}$ と $\mathrm{PaCO}_{2}$ は 4 種類の人工肺で 差はなく, 適正值を維持することができ, 臨床使用上問題がないものと考えられる。

Key words : ガス交換能, MENOX6000 $\alpha$, Capiox RX, QUANTUM HF, QUADROX

\section{I. 緒 言}

近年, 膜型人工肺の性能の進歩は著しく, 次々と 新しい人工肺が開発されている。特にガス交換能に おいては, 臨床使用において充分に満足な成績を示 している。しかしながら, 数種類の人工肺を同時期 に性能比較した報告は少ない。

今回我々は，4種類の人工肺を使用する機会を得 たので, それらのガス交換能について比較検討した ので報告する。

\section{I. 対象および方法}

\section{I. 使用膜型人工肺}

使用した膜型人工肺は，大日本インキ社製 MENOX AL-6000 $\alpha$ (以下, MX) 膜面積 $1.3 \mathrm{~m}^{2}$, テ ルモ社製 Capiox RX $25 \mathrm{R}$ (以下, CP) 膜面積 2.5 $\mathrm{m}^{2}$, Life Stream 社製 QUANTUM HF-6700 (以下, QT) 膜面積 $1.9 \mathrm{~m}^{2}$, Jostra 社製 QUADROX (以下, $\mathrm{QX)}$ 膜面積 $1.8 \mathrm{~m}^{2}$ の 4 種類である。

\section{2. 対 象}

対象は平成 11 年 11 月から平成 13 年 6 月までの 成人開心術症例で, MX 10 例, CP 9 例, QT 16 例，QX 14 例で詳細は表 1 に示す。

3. 方 法

体外循環開始 10 分, 30 分, 以降 30 分おきに完全 体外循環中に人工肺入口と人工肺出口から採血し, 血液ガス分析を行った。なお, 今回は臨床使用での ガス分析であるため, 血液ガス分析の総数は MX 28 回, CP 15 回, QT 40 回, QX 17 回であった。 採血時の体温は 37 2 $5^{\circ} \mathrm{C}$ 範囲であった。体外循環

・天理よろづ相談所病院 臨床病理部

1) 同臟血管外科
は血流量 $2.4 \mathrm{~L} / \mathrm{min} / \mathrm{m}^{2}, \mathrm{FiO}_{2}$ を $80 \%$ で開始し，そ の後の調整は $\mathrm{SvO}_{2} 70$ \%以上, $\mathrm{PaO}_{2} 200 \mathrm{mmHg}$ 以 上, $\mathrm{PaCO}_{2} 40 \mathrm{mmHg}$ を目標に行った。ただし, $\mathrm{FiO}_{2}$

表 1 対象症例

\begin{tabular}{|c|c|c|c|c|}
\hline 人工肺 & 身長 & 体重 & 体表面積 & 疾 患 \\
\hline $\begin{array}{l}\text { MENOX } \\
\mathrm{AL}-6000 \alpha \\
(\mathrm{n}=10)\end{array}$ & $161.7 \pm 7.3$ & $63.2 \pm 10.2$ & $1.67 \pm 0.15$ & \begin{tabular}{|ll} 
虚血性心疾患 & 9 例 \\
大動脈疾患 & 1 例
\end{tabular} \\
\hline $\begin{array}{l}\text { Capiox } \\
\text { RX25R } \\
(n=9)\end{array}$ & $159.6 \pm 10.1$ & $61.9 \pm 18.5$ & $1.63 \pm 0.28$ & \begin{tabular}{|ll} 
虚血性心疾患 & 5 例 \\
弁膜疾患 & 3 例 \\
先天性心疾患 & 1 例
\end{tabular} \\
\hline $\begin{array}{c}\text { QUANTUM } \\
\text { HF-6700 } \\
(\mathrm{n}=16)\end{array}$ & $154.7 \pm 7.3$ & $54.6 \pm 10.2$ & $1.52 \pm 0.16$ & $\begin{array}{l}\text { 虚血性心疾患 } 15 \text { 例 } \\
\text { 大動脈疾患 } 1 \text { 例 }\end{array}$ \\
\hline $\begin{array}{l}\text { QUADROX } \\
(n=14)\end{array}$ & $158.7 \pm 8.4$ & $52.9 \pm 9.9$ & $1.52 \pm 0.17$ & 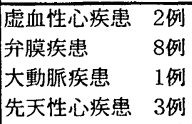 \\
\hline
\end{tabular}

表 2 ガス交換能の指標

酸素添加量 $=\left(\mathrm{CaO}_{2}-\mathrm{CvO}_{2}\right) / 100 \times \mathrm{Q}$

有効肺血流量率 $(\mathrm{Qp} / \mathrm{Qt})=$

$$
\left(\mathrm{CaO}_{2}-\mathrm{CvO}_{2}\right) /\left(\mathrm{Cc}^{\prime} \mathrm{O}_{2}-\mathrm{CvO}_{2}\right)
$$

炭酸ガス排出量 $=\left(\mathrm{CvCO}_{2}-\mathrm{CaCO}_{2}\right) / 100 \times \mathrm{Q}$

炭酸ガス較差分圧比 $\left(\Delta \mathrm{CO}_{2} / \mathrm{PaCO}_{2}\right)=$

$$
\left(\mathrm{CvCO}_{2}-\mathrm{CaCO}_{2}\right) / \mathrm{PaCO}_{2}
$$

$\mathrm{Q}=$ 血流量 $(\mathrm{m} \ell / \mathrm{min})$

$\mathrm{CaO}_{2}=$ 人工肺出口酸素含有量 (vol\%)

$\mathrm{CvO}_{2}=$ 人工肺入口酸素含有量 $(\mathrm{vol} \%)$

$\mathrm{Cc}^{\prime} \mathrm{O}_{2}=1.34 \times \mathrm{Hb}+0.003 \times(760-47)(\mathrm{vol} \%)$

$\mathrm{CaCO}_{2}=$ 人工肺出口炭酸ガス含有量 (vol\%)

$\mathrm{CvCO}_{2}=$ 人工肺入口炭酸ガス含有量 (vol\%) 
は $60 \sim 80 \%$, 酸素血流比(以下, $\mathrm{V} / \mathrm{Q}$ ) は $0.5 \sim 0.7$ の範囲で調節した。ガス交換能は酸素加能の指標と して $\mathrm{PaO}_{2}$, 酸素添加量および有効肺血流量率(以 下, $\mathrm{Qp} / \mathrm{Qt}$ ), 炭酸ガス排出能の指標は $\mathrm{PaCO}_{2}$, 炭酸 ガス排出量㧍よび炭酸ガス較差分圧比(以下, $\left.\Delta \mathrm{CO}_{2} / \mathrm{PaCO}_{2}\right)$ にて評価した ${ }^{1)}($ 表 2$) 。$

統計学的検討は多重比較法 (Newman-Keuls 検 定）を用い, $\mathrm{p}<0.05$ をもって有意とした。なお，身 長, 体重, 体表面積において 4 種の症例間で有意差 はなかった。

\section{III. 結 果}

\section{I. 酸素加能}

$\mathrm{PaO}_{2}$ の平均值は $\mathrm{MX}: 366 \pm 41 \mathrm{mmHg}, \mathrm{CP}$ : $370 \pm 63 \mathrm{mmHg}$, QT : $355 \pm 57 \mathrm{mmHg}, \mathrm{QX}: 384 \pm$ $64 \mathrm{mmHg}$ と 4 種間に有意差はなかった(図 1 )。酸 素添加量の平均值は $\mathrm{MX}: 108 \pm 15 \mathrm{~mL} / \mathrm{min}, \mathrm{CP}$ : $104 \pm 38 \mathrm{~mL} / \mathrm{min}, \mathrm{QT}: 111 \pm 20 \mathrm{~mL} / \mathrm{min}, \mathrm{QX}$ : $90 \pm 22 \mathrm{~mL} / \mathrm{min}$ と, QT と MX が QX に対して有意

$$
\mathrm{mmHg}
$$

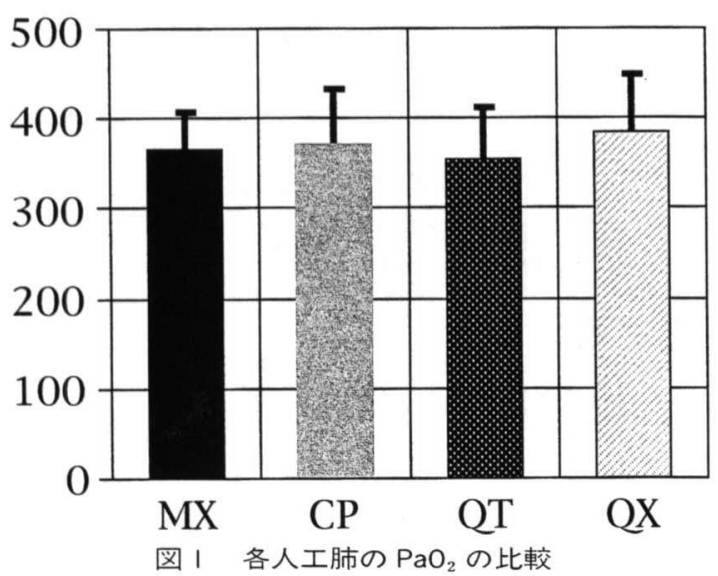

$\mathrm{m} \ell / \mathrm{min}$

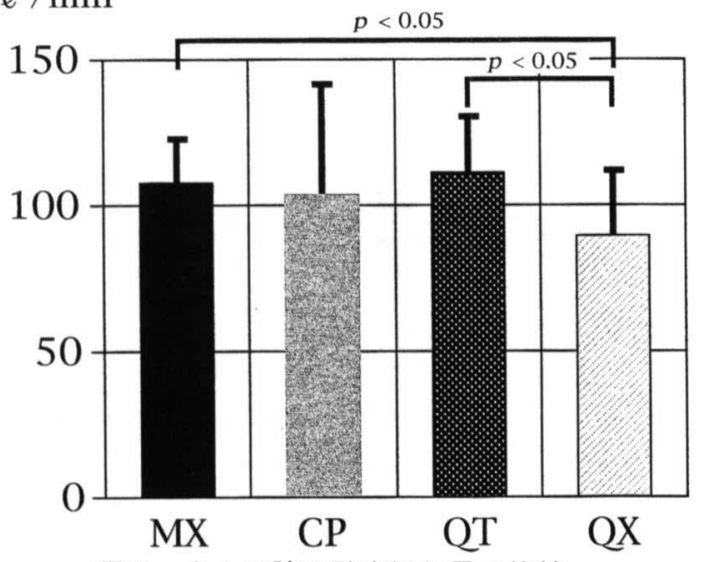

図 2 各人工肺の酸素添加量の比較
に高值となった (図 2 )。 $\mathrm{Qp} / \mathrm{Qt}$ の平均值は, $\mathrm{MX}$ ： $0.72 \pm 0.04, \mathrm{CP}: 0.69 \pm 0.09$, QT $: 0.73 \pm 0.04$, $\mathrm{QX}: 0.71 \pm 0.07$ と 4 種間に有意差はなかった(図 3 )。

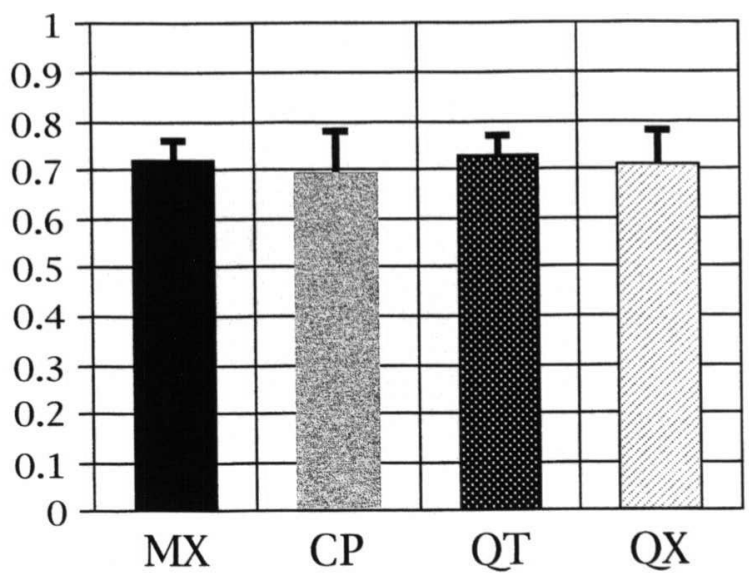

図 3 各人工肺の Qp/Qt の比較

$\mathrm{mmHg}$

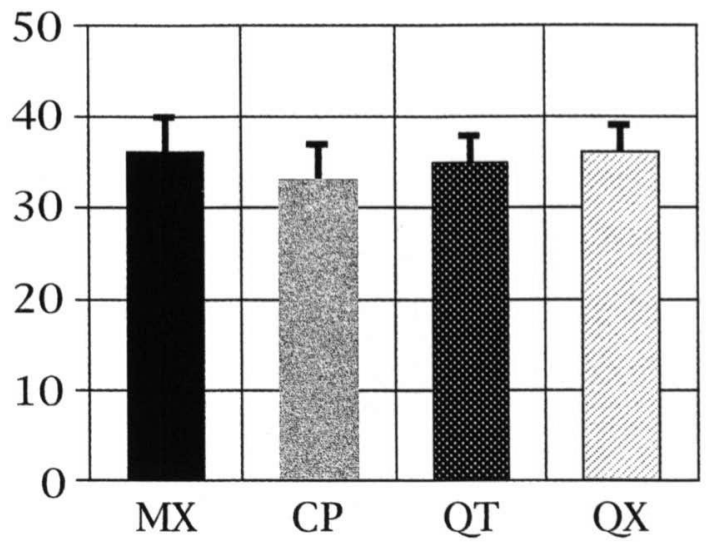

図4 各人工肺の $\mathrm{PaCO}_{2}$ の比較

$\mathrm{m} \ell / \mathrm{min}$

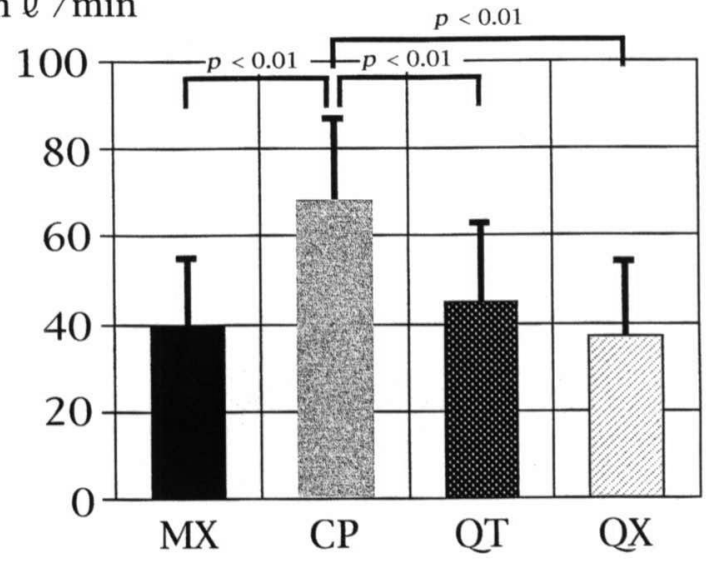

図 5 各人工肺の炭酸ガス排出量の比較 


\section{2. 炭酸ガス排出能}

$\mathrm{PaCO}_{2}$ の平均值は $\mathrm{MX}: 36 \pm 4 \mathrm{mmHg}, \mathrm{CP}: 33 \pm$ $4 \mathrm{mmHg}$, QT : $35 \pm 3 \mathrm{mmHg}$, QX : $36 \pm 3 \mathrm{mmHg}$ と 4 種間に有意差はなかった (図 4 )。炭酸ガス排出 量の平均值は, $\mathrm{MX}: 40 \pm 15 \mathrm{~mL} / \mathrm{min}, \mathrm{CP}: 68 \pm 19$ $\mathrm{mL} / \mathrm{min}$, QT : $45 \pm 18 \mathrm{~mL} / \mathrm{min}, \mathrm{QX}: 37 \pm 17 \mathrm{~mL} /$ $\min$ と $\mathrm{CP}$ が他より有意に高值を示した(図 5 )。 $\Delta \mathrm{CO}_{2} / \mathrm{PaCO}_{2}$ は, $\mathrm{MX}: 0.03 \pm 0.01 \mathrm{vol} \% /$ $\mathrm{mmHg}, \mathrm{CP}: 0.05 \pm 0.01 \mathrm{vol} \% / \mathrm{mmHg}$, QT : $0.03 \pm 0.01 \mathrm{vol} \% / \mathrm{mmHg}$, QX : $0.03 \pm 0.02 \mathrm{vol}$ $\% / \mathrm{mmHg}$ と $\mathrm{CP}$ が他より有意に高值となった(図 6 )。

3. 各項目の体外循環中の経時的変化

$\mathrm{PaCO}_{2}$, 酸素添加量, $\mathrm{Qp} / \mathrm{Qt}, \mathrm{PaCO}_{2}$, 炭酸力゙ス 排出量, $\Delta \mathrm{CO}_{2} / \mathrm{PaCO}_{2}$ の項目の経時的変化は, 4 種 類とも有意に低下することなく, 90 分間推移した (図 7〜12)。ただし, 体外循環開始 30 分と90 分につ

vol $\% / \mathrm{mmHg}$

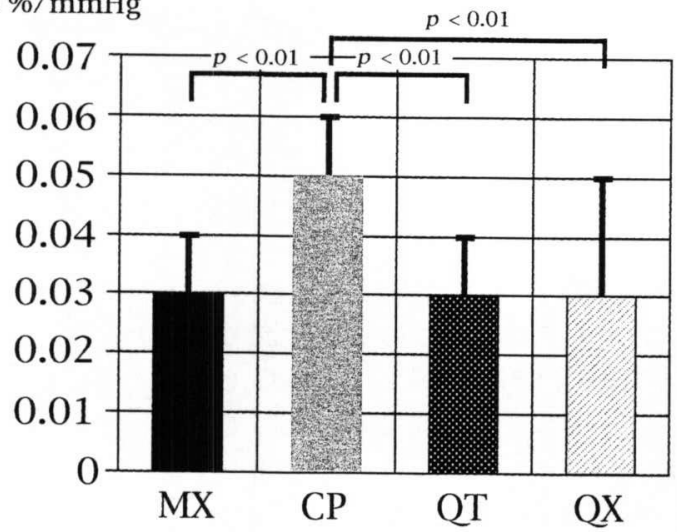

図 6 各人工肺の $\Delta \mathrm{CO}_{2} / \mathrm{PaCO}_{2}$ の比較

$\mathrm{mmHg}$

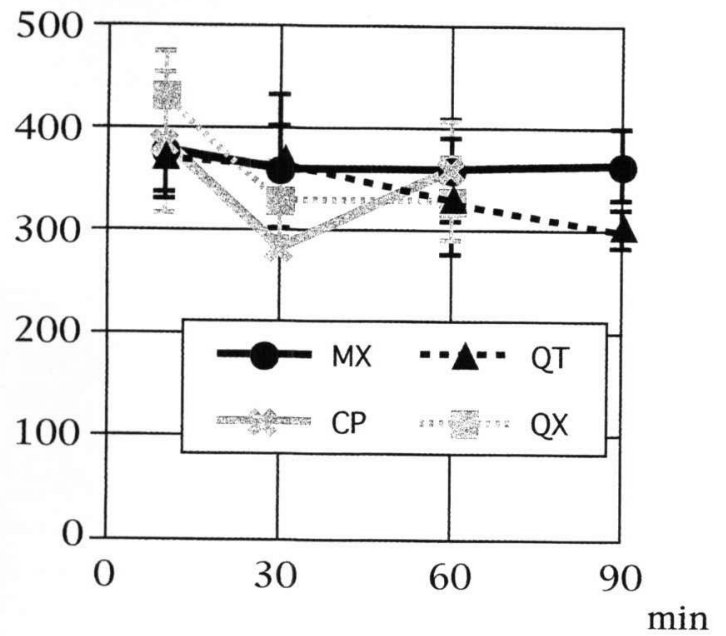

図 7 各人工肺の $\mathrm{PaO}_{2}$ の経時的変化 $\mathrm{m} \ell / \mathrm{min}$

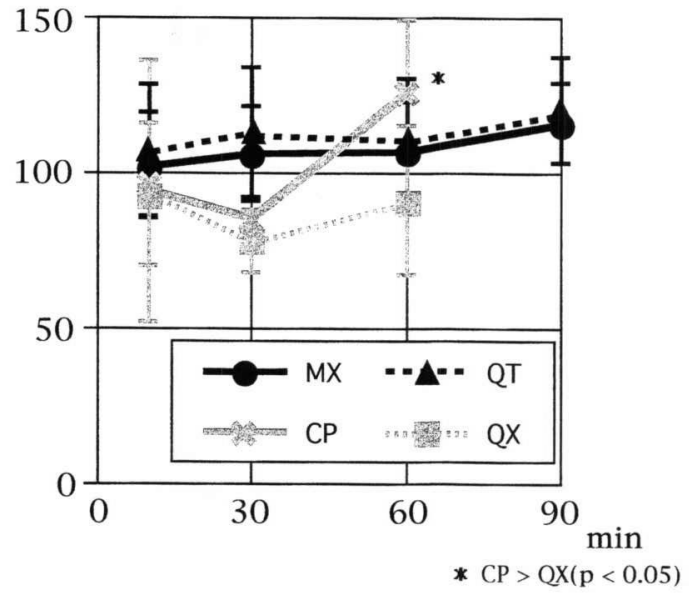

図 8 各人工肺の酸素添加量の経時的変化

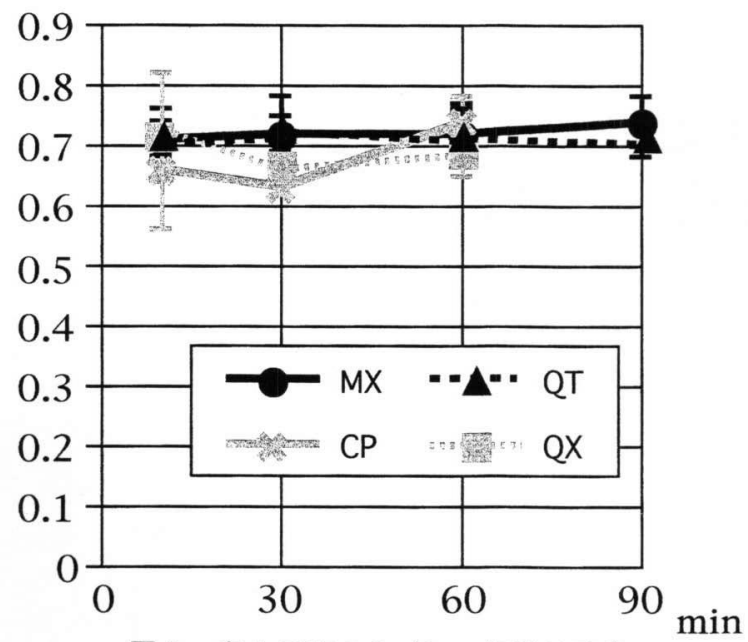

図 9 各人工肺の $\mathrm{Qp} / \mathrm{Qt}$ の経時的変化

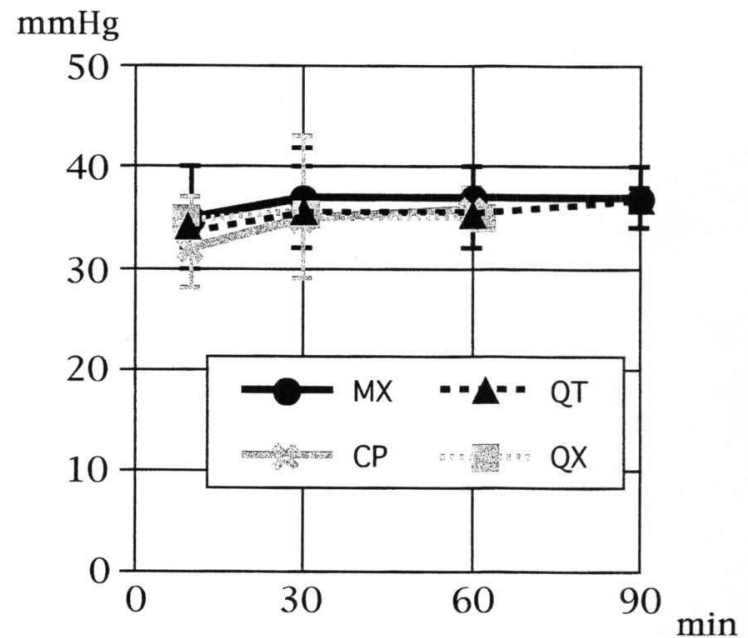

図 10 各人工肺の $\mathrm{PaCO}_{2}$ の経時的変化 
いては, サンプル数が少ないため統計学的検討は行 えなかった。

\section{4. 血流量, $\mathrm{FiO}_{2}, V / Q$}

採血時の血流量は, $\mathrm{MX}: 3.9 \pm 0.4 \mathrm{~L} / \mathrm{min}, \mathrm{CP}$ : $4.3 \pm 0.6 \mathrm{~L} / \mathrm{min}, \mathrm{QT}: 3.8 \pm 0.5 \mathrm{~L} / \mathrm{min}, \mathrm{QX}: 3.6 \pm$ $0.6 \mathrm{~L} / \mathrm{min}$ と CP が他より有意に高值となった。 $\mathrm{FiO}_{2}$ は 4 種間に有意差はなかった。 $\mathrm{V} / \mathrm{Q}$ は, $\mathrm{MX}$ ： $0.68 \pm 0.12, \mathrm{CP}: 0.57 \pm 0.14$, QT $: 0.60 \pm 0.09$, $\mathrm{QX} ： 0.55 \pm 0.12$ と $\mathrm{MX}$ が他より少し高くなった。

\section{IV. 考 察}

近年における膜型人工肺の性能の進歩は著しい。 特にガス交換能においては, 開心術症例の短期使用 では充分に満足のできる成績を示している年4)。か し, 高性能の人工肺を新たに使用するにあたっては,

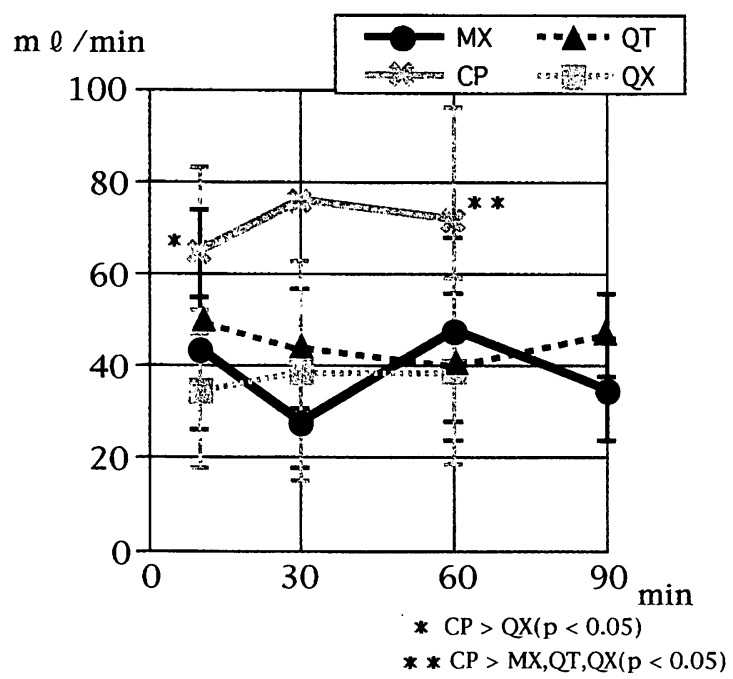

図１1各人工肺の炭酸ガス排出量の経時的変化

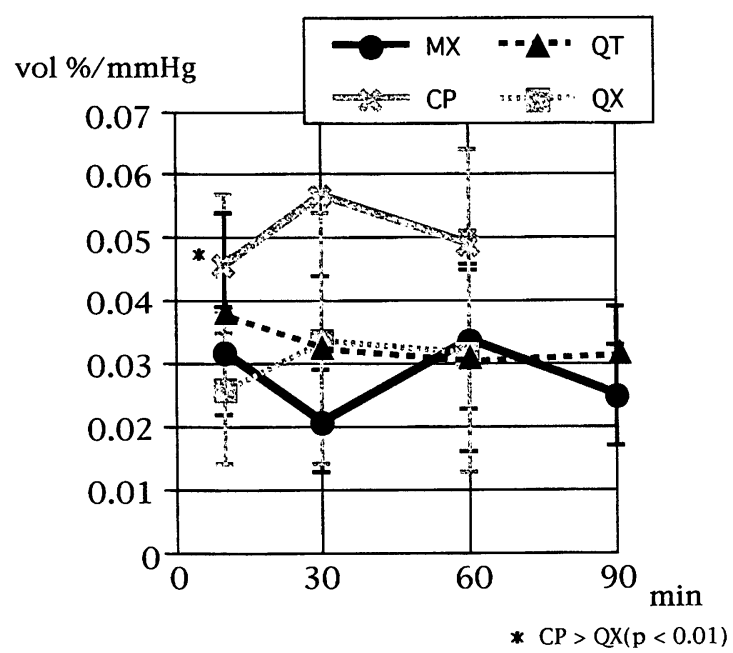

図 12 各人工肺の $\Delta \mathrm{CO}_{2} / \mathrm{PaCO}_{2}$ の経時的変化
ガス交換能などの基礎的な検討を行ってから採用す ることは重要なことである。

今回検討した 4 種類の膜型人工肺について, 酸素 加能は酸素添加量において QT と MXが QX に対 して高值となった。しかし, Qp/Qt の指標ではこの 傾向が認められず 4 種類とも同程度であった。QT はポリプロピレン中空糸膜の外部潅流型膜型人工肺 で, 酸素加部の中空系の巻き付け法に二重マット方 式を採用しているのが特徵である5)。MX は二重構 造ポリオレフィン中空糸膜の外部潅流型膜型人工肺 で， $\alpha$ シリーズでは中空系の細径化と䈴密度の向上 を行っているのが特徵であるあ。これらの工夫によ って酸素添加量において高值を示した可能性がある が, Qp/Qt においては高值を示さなかったことか ら, QT と MX の酸素加能の性能は, 他よりそれほ ど高いものではないと推測する。

炭酸ガス排出能は, $\mathrm{CP}$ は炭酸ガス排出量と $\Delta \mathrm{CO}_{2} / \mathrm{PaCO}_{2}$ において高值を示した。炭酸ガス排出 量と $\Delta \mathrm{CO}_{2} / \mathrm{PaCO}_{2}$ は, 血流量が増加すれば炭酸ガス 排出量が高値となり, $\Delta \mathrm{CO}_{2} / \mathrm{PaCO}_{2}$ は低值になると 報告されている7)。今回の検討においては，CP の血 流量の平均は他より高値となっており, このために 炭酸ガス排出量が高くなった可能性がある。しかし, この傾向では $\Delta \mathrm{CO}_{2} / \mathrm{PaCO}_{2}$ は低値となるはずであ るが, 結果は逆に高值となった。以上のことより, $\mathrm{CP}$ の炭酸ガス排出能は血流量を考慮しても, 他よ り高い性能を示していると推測できる。

$\mathrm{CP}$ は X コーティング処理したポリプロピレン中 空糸膜の外部潅流型膜型人工肺で, ウーブンタイプ のファイバーモジュールデザインを採用して，膜面 積が $2.5 \mathrm{~m}^{2}$ となっている。このガス交換部の工夫 と, 膜面積が他の人工肺より大きく設定してあるこ とにより, 高い炭酸ガス排出能を有していると考え られる。

酸素加能と炭酸ガス排出能の経時的変化は, 劣化 することはなく性能を維持することができた。この ことより, 開心術症例の短期使用では問題なく使用 できることが理解できる。

以上のことから, 酸素加能においては QT と MX が良好な性能を示し, 炭酸ガス排出能では CP が高 性能を示した。しかし, $\mathrm{PaO}_{2}$ と $\mathrm{PaCO}_{2}$ は 4 種類間で 差はなく, 適正值を維持することができ, 臨床使用 上問題がないものと考えられる。

\section{V. 結 語}

酸素加能は QT と MX が良好であった。炭酸がス 排出能はすべての指標において $\mathrm{CP}$ が最も高い性能 を示した。 $\mathrm{PaO}_{2}$ と $\mathrm{PaCO}_{2}$ に関して, 4 種類の人工肺 に有意差はなく, 適正值を維持することができ, 臨 床使用には何ら問題はない。 
○参考文献

1) 野村 望, 川島康生, 藤田 毅, ほか：人工肺ガス 交換能の指標に関する研究. 日胸外会誌, 23(12)； 1402-1411, 1976.

2 ) 湯浅 毅, 碓水章彦, 大島英揮, ほか：新しいシリ コンコーティング膜型人工肺 (エクセランプライム) の性能評価について. 膜型肺, $20 ； 40-43 ， 1997$.

3 ) 大島英揮, 廣浦 学, 村上文彦, ほか：新しいへパ リンコーティング膜型人工肺(QUADROX-Bioline coating Jostra)の使用経験. 膜型肺，21；23-27, 1998.

4 ）上屋敷繁樹, 橋本和弘: Hollow Fiber 型膜型人工 肺 D 903 の臨床経験一ヘパリンコーティング膜型人 工肺との比較一. 膜型肺, $23 ； 21-25,2000$.
5 ）福田勇司, 原 敏郎, 島本 健, ほか：膜型人工肺 QUANTUM HF-6700 の臨床使用経験一膜型人工肺 CAPIOX SX $-18 \mathrm{R}$ との比較一. 体外循環技術, 26 (1) ; 43-46, 1999.

6 ) 吉岡政美, 飯塚嗣久, 笹盛幹文, ほか：膜型人工肺 MENOX AL- $6000 \alpha$ の臨床使用経験-MENOX AL6000 との比較一. 体外循環技術, 26(4)；34-38, 1999.

7 ）高野久輝, 川島康生, 藤田 毅, ほか：膜型人工肺 (Lande Edwards 型) の換気特性の検定. 人工臓器, $4 ; 75-80,1975$.

[本論文は, 第 27 回日本体外循環技術研究会大会にて 